\title{
Leadership Competencies and Commitment to Change: The Mediating Effect of Developmental Leadership Behavior
}

\author{
Fanny Kho Chee Yuet \\ Universiti Pendidikan Sultan Idris, Malaysia, fannykcy@fpe.upsi.edu.my
}

\begin{abstract}
Leading change from the classroom is closely linked with the development of teacher leaders. It is considered to be the significant outcome of teachers' commitment to change their ordinary role as classroom instructional leaders to school-based teacher leaders. In this regard, it is a privilege for teacher leaders to walk with principals who portray developmental leadership behavior competently. Thus, the objective of this study is to test a theory-based model predicting teachers' leadership competencies and its relationship with principals' developmental leadership behavior and teachers' commitment to change. Data was collected from 928 respondents who served in 58 high performing secondary schools in Malaysia. Structural Equation Modeling was utilized to test the model developed. The results indicate that the teachers' leadership competencies have significant relationship with principals' developmental leadership behavior and teachers' commitment to change. In addition, principals' developmental leadership behavior was found to mediate the relationship between teachers' leadership competencies and teachers' commitment to change.
\end{abstract}

Keywords: leadership competencies, developmental leadership behavior, commitment to change, teacher leaders

\section{INTRODUCTION}

Last decade research has emphasized on teachers' new role as instructional leaders (DarlingHammond, 1999; Hill \& Amabile, 1993; Crowther, 2002a \& 2002b). In other words, teachers should portray leadership values and perform as leaders particularly in creating effective instructional practices based on their specialized area which will contribute to school improvement (Andrews, Crowther, Hann \& McMaster, 2002). The emphasis on school improvement would greatly depend on the effectiveness of shared leadership approach implemented in school (Chesterton \& Duignan, 2004).

In fact, the norm of shared approach requires teachers to share leadership responsibilities with principals (Crowther et al, 2002a \& 2002b). Principals, on the other hand, need to distribute leadership responsibilities among teachers (Lashway, 2003; Pearce \& Sims, 2002; Harris, 2002; Spillane, Halverson \& Diamond, 2001; and Elmore, 2000). Similarly, Pearce and Sims (2002) had conducted a research on ways leadership is distributed, as well as distributive influence of positional leaders and effectiveness of shared leadership of informal leaders, in which leadership practice in schools was assigned as the unit of analysis.

Elmore (2000), too, emphasized that leadership in schools need to be distributed among school communities, in which expertise is incorporated within a culture of coherence, collaborative work, guidance and direction for improvement of instructional practice (Katz, Earl \& Jaafar, 2009). 
Silins and Mulford (2002) believe that a whole-school re-structuring require teachers to engage in leadership responsibilities and students' development. Distributed leadership therefore, need to be relocated to other school communities as well (MacBeath, 1998; Day, Harris \& Hadfield, 2001; Harris 2002).

With respect to support whole school re-structuring process, Harris (2002) revealed that strong collegial relationship, trustworthy, supportive, enquiry-based focused are essential factors for effective school reform to occur. The underlying norms, values, beliefs, and assumptions in the collegial relationship also lead to effective teamwork among teachers (Peterson, 1994). Silins and Mulford (2002), provide evidence that students' achievement will improve when teachers are empowered in decision making particularly on the effectiveness of instructional practices and assessment.

Nonetheless, empowerment is hardly to establish and maintain in practice if leadership is not individually desired and distributed (Harris, 2002). Hence, principals need to find ways to influence teachers to assume leadership role as classroom instructional leaders while providing support and resources in changing current individualistic instructional practices to collaborative practices. Obviously, a new paradigm in teaching profession is needed to provide new forms of leadership in schools and communities (Crowther et al., 2002a).

Indeed, teachers' role as 'leaders' would be enhanced if they perform as 'leaders' in the professional development community, as well as members of school-wide leadership teams and instructional support teams (Childs-Bowen, Moller, \& Scrivner, 2000; Camegie Forum on Education and the Economy, 1986; Holmes, 1986; Elmore, 2002; Livingston, 1992). Simply stated, teachers are more competent in initiating change in a comprehensive and continuous manner (Howey, 1988; Livingston, 1992), without necessary leaving the classroom.

In fact, the task of initiating effective reform requires a multi-dimensional set of leadership competencies (Day \& Harris, 2002). Competencies is one of the three critical factors that contribute to successful school reform, followed by commitment and capability (Marcus \& Pringle, 1995). Identifying competencies is significantly important in the leadership development puzzle (Yamazaki \& Kayes, 2004) as it has a great influence in teacher leadership success in schools, and can be fine-tuned for greater efficiency in leading change from the classroom (Teacher Leadership Exploratory Consortium, 2011; Tubbs \& Schulz, 2006).

\section{CONCEPTUAL FRAMEWORK AND THEORETICAL FOUNDATION}

The conceptual framework of the present study seeks to comprehend and clarify whether Teachers' Leadership Competencies (TLC) is a multidimensional concept by distinguishing the crucial leadership competencies that facilitate school change, and how these perceived competencies influence Principals' Developmental Leadership Behavior (PDLB) and Teachers' Commitment to Change (TCC). TLC function as Independent Variable (IV), TCC as Dependent Variable (DV) while PDLB function as Mediating Variable (M) of the study (Figure 1).

Basically, the study was constructed to three latent variables and thirteen of their respective indicators are chosen to estimate the variables as shown below: 
a) Latent construct 1: Teachers' Leadership Competencies (TLC) which is measured by five indicators, i.e.

i) Facilitating Improvement and Establishing Standards (FIES);

ii) Modeling Leadership Attributes and Skills (MLAS);

iii) Participating in Organizational Development (POD);

iv) Fostering a Collaborative Culture (FCC); and

v) Performing as Referral Leader (PRL);

b) Latent construct 2: Principals' Developmental Leadership Behavior (PDLB) which is measured by five indicators, i.e.

i) Focused (FOC);

ii) Supportive (SUP);

iii) Developer $(D E V)$;

iv) Competitive (COM); and

v) Charismatic (CHA).

c) Latent construct 3: Teachers' Commitment to Change (TCC) which is measured by three indicators, i.e.

i) Personal Goals (PEG);

ii) Capacity Beliefs (CAB); and

iii) Context Beliefs (COB)

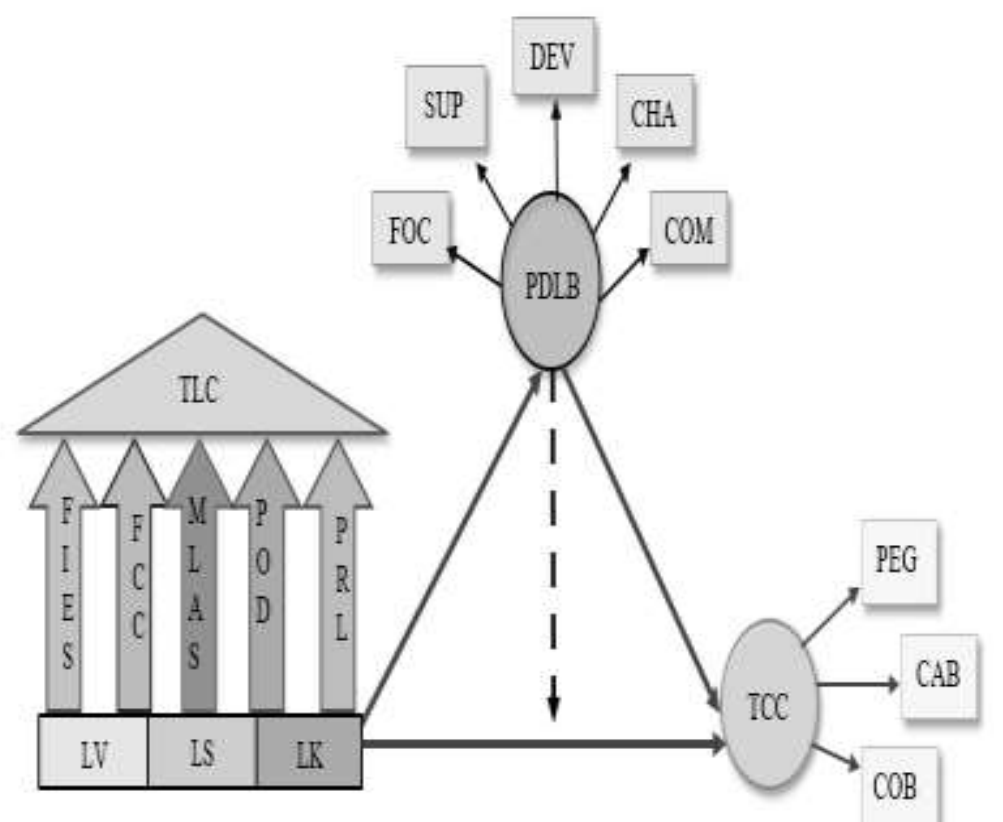

Figure 1: The Proposed Conceptual Framework of the Study 
The conceptual framework in the present study emphasis on the research purposes, objectives and relationship based on the underlying theoretical perspectives which support the research design, assisting the researcher in justifying the research and to successfully achieve the objectives of the study as well, not only to bear in mind the three latent variables and the thirteen key indicators as discussed above.

Ultimately, the framework was established by integrating results and theories or models which gradually developed: Distributed Leadership Theory (Gronn, 2002; Spillane, Halverson, \& Diamond, 2004; Spillane, 2006), Leadership Competencies Theory (McCall, 1998; Conger, 1999; Charan, Drotter, \& Noel., 2000; Tichy \& Cardwell, 2002), Skills-Based Leadership Theory (Danielson, 2006), Knowledge-Based Leadership Theory (Fullan,1994), Values-Based Leadership Theory (Daft, 2005), Competency Theory (Boak \& Coolican, 2001; Cairns, 2000), Transformational Leadership Theory (Burn, 1978; Avolio, Waldman \& Einstein, 1988; Bass, 1990), Motivation Theories (Ford, 1992 \& Bandura, 1986), and Social Learning Theory (Bandura, 1977). The proposed conceptual framework qualifies an inclusive analysis of all connected domains and the comprehensive coherence was constructed based on pertinent theories and models (Figure 1).

\section{POPULATION AND SAMPLE}

The study population encompassed of 16,892 High Performing Secondary Schools (HPSS) teachers in Malaysia (KPM, 2014). The HPSS teacher leaders' competency in leading change is far higher than teacher leaders in mediocre or low-performing. As a result, principals in HPSS experienced developing teacher leaders more often than their counterparts in mediocre or lowperforming schools. Hence, by focusing on HPSS, the researchers can more accurately evaluate the critical component of Principal's Developmental Leadership Behavior (PDLB).

Multiple-staged stratified random sampling procedure was utilized in this study. Basically, there were three strata in the study population, and as a result 87 Daily Secondary School (DSS), 91 Fully Residential Secondary School (FRSS) and 50 Religious Secondary School (RSS) or a total of 228 HPSS were selected randomly through the proportionate stratification procedure for the survey. Next, the proportionate stratification procedure was applied again to stratify the HPSS in each state, respectively. This sampling technique gives all the three strata in each state equal chances of being selected. After the stratification of school is made, then the sample was identified.

With 58 schools identified, 16 respondents of teachers from each school were chosen as the sample by using the simple sampling method based on the official list of teachers provided by the State Education Departments, respectively. As a result, 352 teachers were selected to represent DSS, 368 for FRSS and 208 for RSS. Overall, a total number of 928 respondents were identified for the survey where this represents $25 \%$ of the total number of teachers in 58 HPSS $(\mathrm{N}=3,665)$. Importantly, it meets the basic requirement of evaluating the overall fit of the hypothesized models using structural equation modeling analysis (SEM) (Chua, 2009; Kline, 2005). 


\section{DATA ANALYSIS AND RESULTS}

\section{The Pooled-CFA to Validate the Measurement Model of TLC-PDLB-TCC Constructs Involved in the Model}

The researcher computes certain measures which indicate the validity and reliability of the pooled TLC-PDLB-TCC construct (Figure 2) and summarize them in Table 1, after successfully complete the CFA procedure for every measurement model. Thus, the assessment for unidimensionality, validity, and reliability for measurement models are performed prior to modeling the structural model.

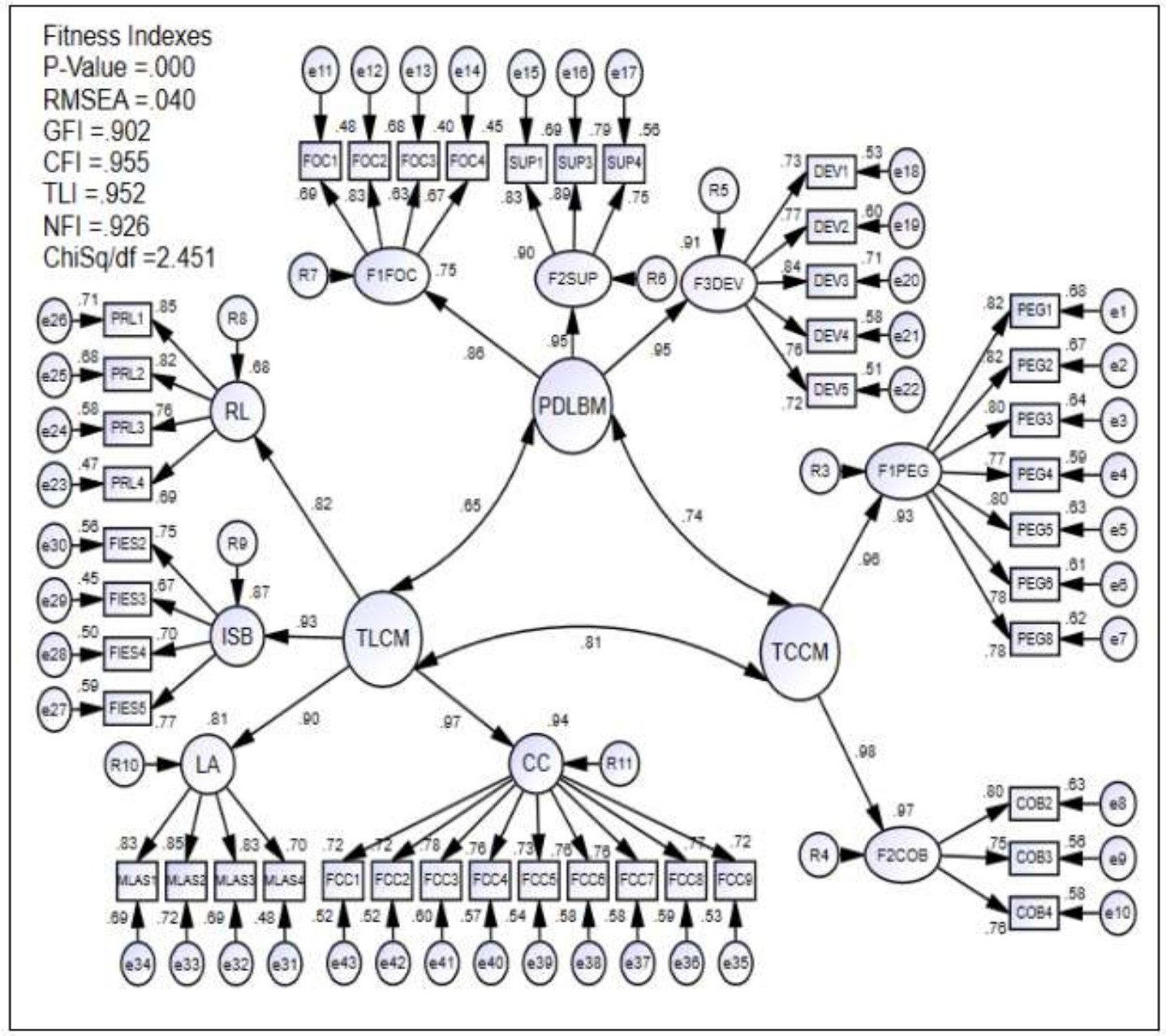

Figure 2: The Pooled Measurement Model of TLC-PDLB-TCC 


\section{Unidimensionality}

Unidimensionality of theTLC-PDLB-TCC constructs is achieved through item-deletion process for low factor loading items. The process is repeated until the fitness indices achieved the required level.

\section{Construct Validity}

Three categories of fit indices were utilized to assess the construct validity of TLC-PDLB-TCC models namely, i) absolute fit indices; ii) relative fit indices; and iii) parsimonius fit indices. The absolute fit indices ( $\mathrm{GFI}=.902)$; the relative fit indices ( $\mathrm{CFI}=.955$; $\mathrm{TLI}=952)$; and the parsimonius fit indices (NFI=.926) has surpassed the threshold value of .90. indicating the construct validity of the TLC-PDLB-TCC models is achieved.

\section{Convergent Validity}

The convergent validity of the TLC-PDLB-TCC models is achieved since all the AVE surpassed the required value of 0.50 (Hair et al., 2006), i.e. TLCM (.832), PDLBM (.849), and TCCM (.961) (Table 1). These values also support the content validity of the TLC-PDLB-TCC models.

Table 1: The CFA Result for Pooed Measurement Model of TLC-PDLB-TCC

\begin{tabular}{ccccc}
\hline Construct & Item & $\begin{array}{c}\text { Factor } \\
\text { Loading }\end{array}$ & $\begin{array}{c}\text { CR } \\
\text { (above 0.6) }\end{array}$ & $\begin{array}{c}\text { AVE } \\
\text { (above 0.5) }\end{array}$ \\
\hline TLCM & FOC/CC & .96 & .952 & .832 \\
& MLAS/LA & .95 & & \\
& FIES/ISB & .92 & & \\
& PRL/RL & .81 & & $\mathbf{. 8 4 9}$ \\
PDLBM & FOC & .86 & $\mathbf{. 9 4 4}$ & \\
& SUP & .99 & & $\mathbf{. 9 6 1}$ \\
& DEV & .91 & & \\
TCCM & PEG & 1.00 & $\mathbf{. 9 8 0}$ & \\
& COB & .96 & & \\
& & & & \\
\hline
\end{tabular}

\section{Discriminant Validity}

Table 2 shown that the diagonal value (in bold) are higher than any other values in its row and column. Thus, the researcher may conclude that the discriminant validity for TLC-PDLB-TCC constructs involved in the model is achieved. The next stage would focus on modelling the structural model (SEM).

Table 2: The Discriminant Validity Index Summary

\begin{tabular}{lccc}
\hline Construct & TLCM & PDLBM & TCCM \\
\hline TLCM & $\mathbf{0 . 9 4}$ & & \\
PDLBM & 0.65 & $\mathbf{0 . 9 5}$ & \\
TCCM & 0.81 & 0.74 & $\mathbf{0 . 9 9}$ \\
\hline
\end{tabular}




\section{The Mediation Test}

In order to test the research question (Does Principals' Developmental Leadership Behavior mediate the relationship between Teachers' Leadership Competencies and Teachers' Commitment to Change?), the study employed the method proposed by Zainudin Awang (2015) in testing for the mediation effects in the model. According to Zainudin Awang (2015), the mediation occurs only if the effects from exogenous construct to the endogenous construct that goes through the mediator (indirect effect) is greater than the effects from the exogenous construct that goes directly to the endogenous (direct effect). In the meantime, the type of mediation would depend on the significance of the direct effect. If the effect is significant, partial mediation will occur. Otherwise, full mediation will occur. Table 3 presents the Path Coefficient and its significance. The results show all paths are significant. Figure 2 presents the standardized path coefficient of the model.

Table 3: The Regression Weights and Its Significance

\begin{tabular}{llcccccc}
\hline & & Estimate & $\begin{array}{c}\text { Std. } \\
\text { Estimate }\end{array}$ & S.E. & C.R. & P & Result \\
\hline PDLBM $<---$ & TLCM & 0.640 & 0.67 & 0.049 & 13.188 & $* * *$ & Significant \\
TCCM $<---$ & PDLBM & 0.757 & 0.58 & 0.055 & 13.698 & $* * *$ & Significant \\
TCCM $<---$ & TLCM & 0.496 & 0.33 & 0.048 & 10.319 & $* * *$ & Significant \\
\hline
\end{tabular}

Figure 3 presents the indirect effect TLCM to TCCM that goes through PDLB is $0.388(0.67 \mathrm{x}$ 0.58 ) and the direct effect TLCM to TCCM is 0.33. Both the indirect and direct effects are also significant. Thus, Partial Mediation occurs since indirect effect is higher than direct effect Muhammad Kashif, Siti Zakiah Melatu Samsi, Zainudin Awang, \& Mahadzirah Mohamad, 2016).

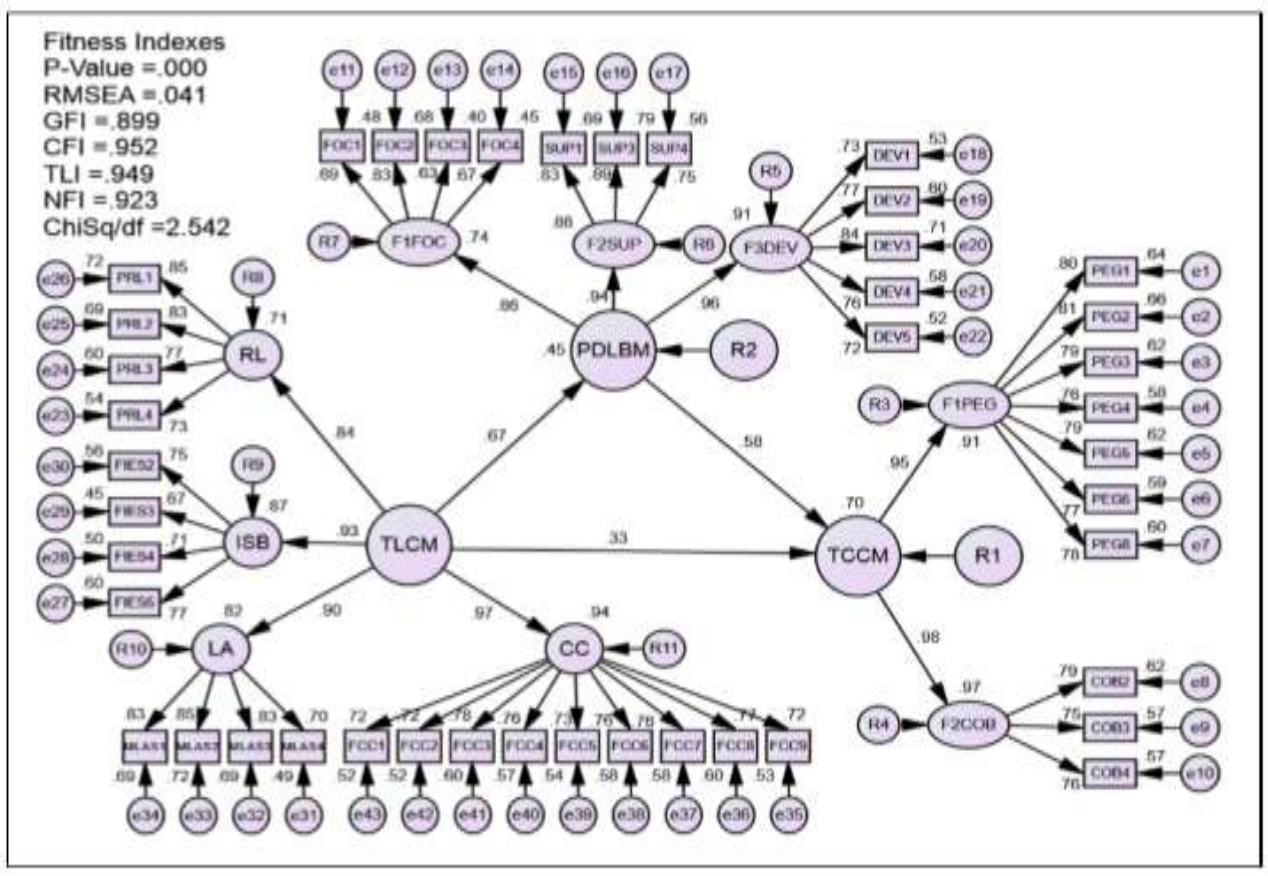

Figure 3: The Regression Path Coefficients between Constructs in the Study 


\section{SUMMARY OF FINDINGS}

The findings of the study would provide input to support the development of teacher leadership model that promotes the inclusion of 2st century leadership values, knowledge and skills. Ultimately, the conceptual framework qualifies an inclusive analysis of comprehensive coherence constructed based on pertinent theories, which contribute to leadership development in any context, individually or organizationally, whereby the perceived developmental leadership behavior function as a critical contributor to commitment to change. In other words, commitment to change are grounded in higher order concept - the perceived developmental leadership behavior.

Besides, the finding also contributes to the understanding of self-regulative influences by which human behavior is altered accordingly. According to Bandura (1999), the impact of most external influences on human action is heavily mediated through self-processes and these permits both insightful and foresightful behavior. Self-influences thus lie at the very heart of causal processes. To cite specific example of this study, principals make causal contributions to their own functioning through cultivation of personal capabilities. In other words, leaders' developmental leadership behavior mediates the relationship between leadership competencies and commitment to change.

Indeed, the above finding was obtained through the application of the social learning theory developed by Bandura (1977). Without this guided theory, it is more likely difficult to conduct a comprehensive analysis which can produce genuine finding. By explicitly focusing on the link among teachers' leadership competencies, principals' developmental leadership behavior and teachers' commitment to change, the researcher indeed started filling the theoretical gaps in the literature.

The finding is also in line with the results of the study conducted by Sarros and Santora (2001), as well as Murphy and Ensher (2008) who claimed that leadership behavior is the most important factor to manage change in an organization which leads to the accomplishment of organizational goals. This view is also congruent with Robbins and Coulter (2009) who revealed that behavioral aspects of leaders serve as an important aspect to train leaders. Besides, DuBrin (2007) definition of leadership also emphasis on the ability of a leader to inspire confident and support among subordinates towards the achievement of organizational goals. Zaccaro and Klimoski (2001), also believed that a leader has the ability to direct subordinates towards the strategic objectives of the organization which is in line with environmental factors.

Apart from these, the finding also in line with Felf and Schyns (2004) research findings that focused on effective leaders as those who practiced transformational leadership style, have great effects on subordinates' behavior in leading their organizations (Tickle, Brownlee, \& Nailon, 2005; Bommer, Rubin, \& Baldwin, 2004), have an important antecedent to construct the collective confidence or strength among subordinates when facing with difficult challenges (Bass \& Avolio, 2003), were able to create significant organizational change and act as change agents, foster higher level of intrinsic motivation, and loyalty among subordinates, introduce a new image of the future, and create commitment among subordinates towards the success of an organization (Kinicki \& Kreitner, 2008; Noorshahi \& Yamani Dozi Sarkhabi, 2008). 
Based on the discussion above, it is noted that school principals need to acquire their effective developmental leadership behavior in developing leadership competencies among teachers due to the great gap between the current state and the desired future state before attempting any school change. Huberman (1973), suggested that focused on the changes in the roles and interpersonal relations' among subordinates i.e. teachers and teachers which leads to teacher leadership, will lead to the success of school change. Likewise, leadership is claimed to be an effective practice in people management that leads to the success of an organization (Prinsloo, Moropodi, Slabbert \& Parker, 1999). Hence, teachers should aware of the current state which needs reform to take place. Indeed, resistance to reform can be overcome when reform is considered as a need by the implementers (Battistich, Schaps, Watson, \& Solomon, 1996; Noblit, Malloy, \& Malloy, 2001), when good relationships are built among or between school staff and parents, and when they are involved in decision-making (Boxall \& Purcell, 2008; Woodruff, Shannon, \& Efimba, 1998); as well as when competencies are increased for successful accomplishment of the reform.

The finding also expands our understanding why school principal needs to support teachers and develop them for in-school capacity (Collins, 2001), and Bishop, Berryman and O'Sullivan (2010) in their research findings that supportive leaders foster committed and agentic teachers. Hersey and Blanchard (1969) also claimed that supportive leaders deal with their subordinates individually and listens to their problems, encourages them in their work, and supports his subordinates socially and emotionally. Evans (1970) and House (1971) too, revealed that supportive leaders interact with the subordinates in a friendly manner and creates a sincere atmosphere with them. They pay attention to their subordinates' tasks and motivate them.

Apart from these, the finding also in line with Bass (1997, 1985), as well as Lim and Ployhart (2004) research findings that supportive leaders have the ability to transform their subordinates towards the creation of new ideas in conducting their tasks and thereby increases the level of task interdependence. In short, all the above research findings support the current finding that leaders' supportive developmental leadership behavior is an important factor in PDLB as it enables principals to assist the teachers in the enhancement of leadership practices, as well as selfdevelopment and self-confidence for school change initiatives.

\section{DIRECTION FOR FUTURE RESEARCH}

As teachers have the potential to exercise new and dynamic leadership in schools (Katzenmayer \& Moller, 1996), and teachers begin to believe in their leadership capabilities, professional community development via teacher leadership is needed (Barth, 2001). Hence, in order to measure a particular development of teacher leadership in the schools involved, a more accurate and adequate evaluation of teachers' reaction toward school principals' developmental leadership behavior is needed. Nonetheless, the data utilized in this study were based on the development of teacher leadership competencies (i.e. TLC) based on four distinct leadership competencies that had been practiced in the school, at a given point in time, respectively.

More specifically, to strengthen the validity of the findings, it would therefore be worthwhile to examine the development of teacher leadership that had been informally initiated at the same time by all the schools involved in the research so as to make the teacher leadership studied more comparable and thus remove the phenomenon of negative stereotype threats (Spencer, Steele, $\&$ 
Quinn, 1999; Steele \& Aronson, 1995; Jordon \& Lovett, 2007) that typically exist in leadership research.

\section{ACKNOWLEDGEMENT}

A highest appreciation goes to the Ministry of Higher Education for the allocation of the research fund under the Niche Research Grant Scheme (NRGS): 2014-0001-107-82-4 (Project 4: Teacher Leadership). It is part of the Development of the Teacher Education Model for Malaysia, led by Professor Dato’ Dr. Noraini Idris.

\section{REFERENCES}

Andrews, D., Crowther, F., Hann, L., \& McMaster, J. (2002). Teachers as leaders: re-imaging the profession. The Practising Administrator, 1, 24-27.

Avolio, B., Waldman, D. \& Einstein, W. (1988). Transformational leadership in a management game simulation: Impacting the Bottom Line. Group \& Organization Management, 13(1), 59-80.

Bandura, A. (1977). Social learning theory. New York: General Learning Press.

Bandura, A. (1986). Social foundations of thought and action: A social cognitive theory. Englewood Cliffs, NJ: Prentice Hall.

Bandura, A. (1999). Social cognitive theory of personality. In L. Pervin \& O. John (Eds.), Handbook of personality $\left(2^{\text {nd }}\right.$ ed.). New York: Guilford Publications.

Barth, R. (2001). Learning by heart. San Francisco: Jossey-Bass.

Bass, B.M. (1990). Bass and Stogdill's handbook of leadership: A survey of theory and research. New York: Free Press.

Bass, B.M. (1985). Leadership and performance beyond expectations. New York: Free Press.

Bass, B.M. (1997). Does the transactional-transformational leadership paradigm transcend organizational and national boundaries? American Psychologist, 52(2), 130-139.

Bass, B. M. \& Avolio, B. J. (2003). The multifactor leadership questionnaire report. Palo Alto, CA: Mind Garden.

Battistich, V., Schaps, E., Watson, M. \& Solomon, D. (1996). Prevention effects of the child development project: Early findings from an ongoing multisite demonstration trial. Journal of Adolescent Research, 11(1), 12-35.

Bishop, R., Berryman, M. \& O’Sullivan, D. (2010). Scaling up Education Reform: Addressing the Politics of Disparity. Wellington: NZCER.

Boak, G. \& Coolican, D. (2001). Competencies for retail leadership: Accurate, Acceptable, Affordable. Leadership and Organizational Development Journal, 22(5), 212-220.

Bommer, H.W., Rubin, R.S. \& Baldwin, T. T. (2004). Setting the stage for effective leadership: Antecedents of transformational leadership behavior. The Leadership Quarterly, 15, 195-210.

Boxall, P. \& Purcell, J. (2008). Strategy and human resource management (2nd ed.). New York: Palgrave Macmillan

Burns, J.M. (1978). Leadership. New York: Harper \& Row 26-33.

Cairns, M. (2000). Leadership Competency Theory. New Straits Times-Management Times.

Camegie Forum on Education and the Economy. (1986). A nation prepared: Teachers for the twenty-first century. The report of the Carmegie Forum on Education and The Economy's Task Force on Teaching as a Profession. Washington, DC: The Forum.

Charan, R., Drotter, S. \& Noel, J. (2000). The Leadership Pipeline: How to Build the Leadership Powered Company. San Francisco: Jossey-Bass.

Chesterton, P. \& Duignan, P. (2004). Evaluation of the national trial of the IDEAS Project. Report to DEST March. 
Childs-Bowen, D., Moller, G. \& Scrivner, J. (2000). Principals: Leaders of leaders. NASSP Bulletin (616), $84,27-34$.

Chua, F.K. (2009). A new object captures attention - but only when you know it's new. Attention, Perception, \& Psychophysics, 71, 699-711.

Collins, J. (2001). Good to great. New York: HarperCollins.

Conger, J. (1999). Building Leaders: How Successful Companies Develop the Next Generation. San Francisco: Jossey-Bass.

Crowther, F., Hann, L. \& Andrews, D. (2002b). Rethinking the Role of the School Principal: Successful School Improvement in the Postindustrial Era. Australia: The Practicing Administrator.

Crowther, F., Kaagan, S.S., Ferguson, M. \& Hann, L. (2002a). Developing Teacher Leaders: How Teacher Leadership Enhances School Success. California: Sage Publications.

Daft, R.L. (2005). The Leadership Experience ( $3^{\text {rd }}$ ed). Canada: South-Western.

Danielson, C. (2006). Teacher leadership that strengthens professional practice. Alexandria, VA: Association for Supervision and Curriculum Development.

Darling-Hammond, L. (1999). Educating teachers: The academy's greatest failure or its most important future? Academe, 85(1),

Day, C. \& Harris, A. (2002). Teacher leadership, reflective practice and school improvement. In K. Leithwood \& P.Hallinger (Eds.), Second international handbook of educational leadership and administration (pp. 957-978). Dordrecht, The Netherlands: Kluwer Academic Publishers.

Day, C., Harris, A. \& Hadfield, M. (2001). Challenging the orthodoxy of effective school leadership. Leadership in Education, 4, 39-56.

DuBrin, A. J. (2007). Leadership research: Findings, practice, and skills (5th ed.). Boston, MA: Houghton Mifflin Company.

Elmore, R.E. (2000). Building a New Structure for School Leadership. Winter: The Albert Shanker Institute.

Evans, M.G. (1970). The effects of supervisory behavior on the path-goal relationship. Organizational Behavior and Human Perormance, 55, 277-298.

Felf, J. \& Schyns, B. (2004). Is similarity in leadership related to organizational outcomes? The case of transformational leadership. Journal of Leadership and Organizational Studies, 10(4), 92-102.

Ford, M. E. (1992). Human Motivation: Goals, Emotions, and Personal Agency Beliefs. Newbury Park, CA: Sage Publications.

Fullan, M.G. (1994). Teacher leadership: A failure to conceptualize. In D.R. Walling (Ed.), Teachers as leaders, pp. 241-253, Bloomington, IN: Phi Delta Kappa Educational Foundation.

Gronn, P. (2002). Leader formation. In K. Leithwood, P. Hallinger, K. Seashore-Louis, G. Furman-brown, P. Gronn, B. Mulford, \& K. Riley. (Eds). Second international handbook of educational leadership and administration, (pp. 1031-1070). Dordrecht: Kluwer.

Hair, J.F., Anderson, R.E., Tatham, R.L. \& Black, W.C. (2006). Multivariate data analysis (5 ${ }^{\text {th }}$ ed.). New Jersey: Prentice Hall.

Hallinger, P. \& Heck, R.H. (1996). Reassessing the principal's role in school effectiveness: A review of empirical research, 1980-1995. Educational Administration Quarterly, 32(1), 5-44.

Harris, A. (2002). Distributed Leadership in Schools: Leading or Misleading. Keynote paper presented at the BELMAS annual conference, Aston University Lakeside Conference Centre, Birmingham, England.

Hersey, P. \& Blanchard, K. (1969). Training \& Development. Alexandria, 50(1), 1-42.

Hill, K. G. \& Amabile, T. M. (1993). A social psychological perspective on creativity: Intrinsic motivation and creativity in the classroom and workplace. In S. G. Isaksen, M. C. Murdock, R. L. Firestien, \& D. J. Treffinger (Eds.), Understanding and recognizing creativity: The emergence of a discipline (pp. 400-432). Norwood, NJ: Ablex.

Holmes Group. (1986). Tomorrow's teachers: A report of the Holmes Group. East Lansing, MI: Author.

House, R.J. (1971). A path-goal theory of leader effectiveness. Administrative Science Quaterly, 16, 321338. 
Howey, K.R. (1988). Why teacher leadership? Journal of Teacher Education, 39(1), 28-31.

Huberman, A. M. (1973). Understanding change in education: An introduction. Experiments and innovations in education no. 4. (ERIC Document Reproduction Service No. ED082330)

Jordon, A.H. \& Lovett, B.J. (2007). Stereotype threat and test performance: A primer for school psychologists. Journal of School Psychology, 45, 45-59.

Katz, S., Earl. L. \& Jaafar, S.B. (2009). Building and connecting learning communities: The power of networks for school improvement. Thousand Oaks, CA: Corwin.

Katzenmeyer, M. \& Moller, G. (1996). Awakening the sleeping giant: Leadership development for teachers. Thousand Oaks, CA: Corwin Press.

Kementerian Pendidikan Malaysia (2014). Institut Pendidikan Guru Malaysia. Kuala Lumpur: Kementerian Pendidikan Malaysia.

Kinicki, A. \& Kreitner, R. (2008). Organizational behavior: key concepts, skills \& best practices (3rd ed.). New York, NY: McGraw-Hill/Irwin.

Kline, R.B. (2005). Principles and practice of Structural Equation Modeling (2 ${ }^{\text {nd }}$ ed.). New York, NY: Guilford.

Lashway, L. (2003). Distributed Leadership (Research Roundup 19, 4). Oregon: ERIC Clearinghouse on Educational Management.

Leithwood, K. \& Jantzi, D. (2000). The Transformational School Leadership Survey. Toronto: OISE/University of Toronto

Lim, B. \& Ployhart, R.E. (2004). Transformational leadership: Relations to the five-factor model and team performance in typical and maximum contexts. Journal of Applied Psychology, 89, 610-621.

Livingston, C. (1992). Introduction: Teacher leadership for restructured schools. In C. Livingston (Ed.), Teachers as leaders: Evolving roles. NEA School Restructuring Series. Washington, DC: National Education Association.

MacBeath, J. (1998). Effective School Leadership: Responding to Change. London: Paul Chapman.

Marcus, S.H. \& Pringle, A. (1995). What competencies are needed in a changing environment? The Human Resources Professional, 8(3), 19-24.

McCall, M. W. (1998). High Flyers: Developing the Next Generation of Leaders. Boston: Harvard Business School Press.

Muhammad Kashif, Siti Zakiah Melatu Samsi, Zainudin Awang, \& Mahadzirah Mohamad. (2016). EXQ: measurement of healthcare experience quality in Malaysian settings - a contextualist perspective. International Journal of Pharmaceutical and Healthcare Marketing, 10, Iss 1 pp. -

Murphy, S. E. \& Ensher, E.A. (2008). A qualitative analysis of charismatic leadership in creative terms: The case of television directors. The Leadership Quarterly, 19, 335-352.

Noblit, G., Malloy, C. \& Malloy, W. (2001). The kids got smarter: Case studies of successful Comer schools. Cresskill, NJ: Hampton Press.

Noorshahi, N. \& Yamani Dozi Sarkhabi, M. (2008). A study of relationship between consequences of leadership style of the president of Iranian universities and institutions of higher education. Available at http://www.academicleadership.org/article/A_study_of_relationship_between_ consequences_of_leadership_and_transformational_leadership_style_of_the_p residents_of_Iranian_universities_and_institutions_of_higher_education

Peterson, K. (1994). Building collaborative cultures: seeking ways to reshape urban schools. Monograph of the North Central Regional Educational Laboratory.

Prinsloo, J. J., Moropodi, M.J., Slabbert, J.A. \& Parker, A.J. (1999). A perspective on the worldclasscompany. Johannesburg: StratExcell (Pty) Ltd.

Robbins, S.P. \& Coulter, M.K, (2009). Management (10th ed.), USA: Prentice Hall.

Sarros, C. J. \& Santora, C. J. (2001). The transformation transactional leadership model in practice. Leadership and Organisation Development Journal, 22(8), 383393 
Silins, H. \& Mulford, B. (2002). Leadership and school results, In K. Leithwood \& P. Hallinger (Eds). International handbook of educational leadership and administration (pp 561-612). Norwell MA: Kluwer.

Spencer, S. J., Steele, C. M. \& Quinn, D. M. (1999). Stereotype threat and women's math performance. Journal of Experimental Social Psychology, 35, 4-28.

Spillane, J.P. (2006). Distributed leadership. San Francisco: Jossey-Bass.

Spillane, J.P., Halverson, R. \& Diamond, J.B. (2004). Towards a theory of leadership practice: A distributed perspective. Journal of Curriculum Studies, 36(1), 3-34.

Spillane, J.P., Halverson, R. \& Diamond, J.B. (2001). Investigating School Leadership Practice: A Distributed Perspective. Educational Researcher, April, 23-28.

Spillane, J. P., Halverson, R. \& Diamond, J.B. (2001). Towards a theory of leadership practice: A distributed perspective. Institute for Policy Research Working Article. Chicago: Northwestern University.

Steele, C. M. \& Aronson, J. (1995). Stereotype threat and the intellectual test performance of AfricanAmericans. Journal of Personality and Social Psychology, 69, 797-811.

Teacher Leadership Exploratory Consortium. (2011). Teacher Leader Model Standards.

Tichy, N.M. \& Cardwell, N. (2002). The Cycle of Leadership: How Great Leaders Teach Their Companies to Win. New York: Collins Business.

Tickle, E. L., Brownlee, J. \& Nailon, D. (2005). Personal epistemological beliefs and transformational leadership behaviours. Journal of Management Development, 24(8), 706-719.

Tubbs, S.L. \& Schulz, E. (2006). Exploring a taxonomy of global leadership competencies and metacompetencies. The Journal of American Academy of Business, 8(2), 35-47.

Tubbs, S.L. \& Schulz, E. (2006). Exploring a Taxonomy of Global Leadership Competencies and Metacompetencies. Journal of American Academy of Business, Cambridge, 8(2), 29-34.

Woodruff, D. W., Shannon, N. R. \& Efimba, M. O. (1998). Collaborating for success: Merritt elementary extended school. Journal of Education for Students Placed at Risk, 3, 11-22.

Yamazaki, Y. \& Kayes, D.C. (2004). An experimental approach to cross-cultural learning: A review and integration of competencies for successful expatriate adaptation. Academy of Management Learning and Education, 3(4), 362-379.

Yamazaki, Y. \& Kayes, D.C. (2004). An experimental approach to cross-cultural learning: A review and integration of competencies for successful expatriate adaptation. Academy of Management Learning and Education, 3(4), 362-379.

Zaccaro, S. J. \& Klimoski, R. J. (2001). The nature of organization leadership. San Francisco, CA: JosseyBass.

Zainudin Awang (2015). SEM Made Simple: A Gentle Approach to Learning Structural Equation Modeling. Bandar Baru Bangi, MPWS Rich Publication. 